\title{
Intraocular Involvement of T and B Cell Lymphomas
}

\author{
E. GRAHAM
}

London

\begin{abstract}
Summary
Six elderly patients with ocular involvement by Non-Hodgkin's lymphoma are reviewed. The characteristic clinical features were a history of fluctuating vision, findings of decreased colour vision, constricted visual fields, vitreous cells and subretinal infiltrates. Fluorescein angiography revealed pigment epithelial abnormalities and attenuated retinal vessels. Non-invasive investigations produced a definite diagnosis in two patients and a presumptive diagnosis in a further three. The ocular involvement was confirmed by vitreous cytology in only one patient: vitreous biopsies in three other patients yielded chronic inflammatory cells and no evidence of lymphoma. The condition responded poorly to steroids but well to radiotherapy.
\end{abstract}

For many years ophthalmologists have recognised that reticulum cell sarcoma may masquerade as a chronic uveitis. ${ }^{1,2,3}$ Recent advances in immunological and cytochemical characterisation of cells have revealed that reticulum cell sarcomas are in fact derived from lymphocytes, not reticulum cells or histiocytes, and hence the diseases are now classified among the non-Hodgkin's lymphomas (NHL). ${ }^{4}$ Eye involvement usually occurs in primary NHL of the eye and the brain rather than in systemic NHL, ${ }^{5}$ and the majority of these lymphomas are of $\mathrm{B}$ cell origin. Although the clinical features of ocular lymphoma are easily recognised: bilateral uveitis with vitreous cells, subretinal infiltrates and pigment epithelial lesions occurring in elderly people,${ }^{6}$ the clinical diagnosis is often difficult to confirm histologically. This study examines six patients with proven lymphoma to find which groups of symptoms and signs might be considered pathognomonic, and to identify which non-invasive investigations are most productive, so that a firm diagnosis can be made without subjecting these elderly and often frail patients to multiple invasive investigations.

\section{Materials and Methods}

All six patients were referred either to the Medical Eye Unit St Thomas' Hospital or to the National Hospital, Queen Square, between 1979 and 1986. Their clinical details are summarised in Table I. The three males and three females ranged in age from 64-80 years. On admission a full ophthalmic and systemic examination was carried out. Investigations included full blood count, sedimentation rate, bone marrow examination, plasma proteins and immunoglobulin estimation, chest X-ray, serum angiotensin converting enzyme, VDRL, CSF examination and CT scan of brain. The diagnosis of NHL was established by vitreous biopsy in one patient, stereotactic biopsy of frontal lobe in one (after 'negative' vitreous biopsies), gastrectomy in one, lymph node biopsy in one and at post mortem in the other two patients. The ocular involvement was therefore confirmed histologically before death in only one patient and based upon the extraocular histology in the other five. Two patients were known cases of NHL prior to onset of ocular

Correspondence to: Dr. E. Graham, Medical Eye Unit, St Thomas' Hospital, London SE1.

From Medical Eye Unit, St Thomas' Hospital, London, SE1. and Department of Neurophthalmology, The National Hospital Queen Square, London WC1.

Presented at the Annual Congress of the Ophthalmological Society of the United Kingdom, April 1987. 
symptoms. All six patients developed cerebral disease; one simultaneously with ocular involvement and the other five at periods ranging from 7 months to 30 months after ocular presentation.

\section{Results}

A. The ocular features are summarised in Table II.

(1) Symptoms The predominant complaint in five patients was 'floaters'. These were variably described as 'black spots', 'jelly curtain', 'like being under water' and 'a large black net'. Patients 1 and 2 commented on a marked diurnal variation in their symptoms at the start of the disease. The vision was much worse in the morning and would gradually clear over a few hours. One patient, a botanic artist, could not work until the afternoons when his vision cleared sufficiently to allow visualisation of the details. After the stage of floaters, four patients developed a progressive deterioration of visual acuity associated with loss of colour definition and tunnelling of the visual field. Patient 4 recalled gradual 'fuzziness' of vision and patient 6 noticed blurred vision but no disturbance in colour perception.
(2) Signs

(i) Visual function. The visual acuity (Snellen) was reduced in all patients except one (patient 6) at the time of onset of ocular symptoms. Two patients each had one eye which was totally blind by the time of admission under our care. The visual field ( $\mathrm{I}_{4}$ Goldmann perimeter) was constricted in all patients but in patients 1 and 2 was reduced to 15 degrees. Colour vision was affected in all except patient 6 . Three patients could not identify any of the Ishihara plates correctly and the remaining 2 patients made a few mistakes with each eye.

(ii) Slit lamp examination. Five patients (all except patient 6) presented with bilateral moderate anterior uveitis associated with fine, evenly distributed keratic precipitates in three patients. Intraocular pressures were raised in patients $3,4,5$, and 6 . All six patients had cells ++ in both vitreous cavities, sometimes accompanied by opacities and debris. The cellular infiltrate in the vitreous contained predominantly large white cells with the occasional smaller white cell and red cell. (iii) Fundus examination. The most distinctive fundus findings were subretinal

Table I Clinical features of six patients with ocular lymphoma

\begin{tabular}{|c|c|c|c|c|c|c|c|c|}
\hline No & Age & Sex & Presenting symptoms & Method of diagnosis & Cell type & $\begin{array}{l}\text { Eye to brain } \\
\text { (months) }\end{array}$ & Treatment & Follow-up \\
\hline 1 & 77 & M & Floaters & Vitreous cytology & $\mathrm{B}$ & 30 & $\begin{array}{l}\text { Radiotherapy } \\
\text { to eye }\end{array}$ & $\begin{array}{l}\text { Good visual } \\
\text { improvement. } \\
\text { Death from } \\
\text { brain tumour }\end{array}$ \\
\hline 2 & 64 & M & Floaters & $\begin{array}{c}\text { Stereotactic biopsy } \\
\text { frontal lobe } \\
\text { ( } 2 \text { negative vitreous } \\
\text { biopsies }\end{array}$ & $\mathrm{B}$ & 7 & $\begin{array}{l}\text { Radiotherapy } \\
\text { to eyes and } \\
\text { brain }\end{array}$ & $\begin{array}{c}\text { Alive } 14 / 12 \\
\text { after } \mathrm{B}\end{array}$ \\
\hline 3 & 72 & $\mathrm{~F}$ & $\begin{array}{l}\text { 1. Epigastric pain } \\
\text { 2. Floaters } 4 \text { years } \\
\text { later }\end{array}$ & $\begin{array}{l}\text { 1. Gastrectomy } \\
\text { 2. (negative vitreous } \\
\text { biopsy) }\end{array}$ & $\mathrm{T}$ & 18 & $\begin{array}{l}\text { Radiotherapy } \\
\text { to eyes and } \\
\text { brain }\end{array}$ & $\begin{array}{l}\text { Alive } 10 / 12 \\
\text { after } \mathrm{B}_{\mathrm{x}}\end{array}$ \\
\hline 4 & 80 & $\mathrm{~F}$ & Blurred vision & Post mortem & $\mathrm{B}$ & 12 & $\begin{array}{c}\text { Radiotherapy } \\
\text { to eyes }\end{array}$ & $\begin{array}{l}\text { Death from } \\
\text { brain tumour }\end{array}$ \\
\hline 5 & 73 & $\mathrm{~F}$ & Blurred vision & Post mortem & $\mathrm{B}$ & 18 & Refused & $\begin{array}{l}\text { Death from } \\
\text { brain tumour }\end{array}$ \\
\hline 6 & 64 & M & $\begin{array}{l}\text { 1. Fever malaise } \\
\text { 2. Blurred vision } 8 \\
\text { months later }\end{array}$ & Lymph node biopsy & $\mathrm{B}$ & Same time & $\begin{array}{c}\text { CHOP* } \\
\text { Radiotherapy }\end{array}$ & $\begin{array}{c}\text { Alive } 8 / 12 \\
\text { after } \mathrm{R}\end{array}$ \\
\hline
\end{tabular}

* CHOP: Cyclophosphamide, Adriamycin, Vincristine. Prednisolone. 
Table II Ocular features on admission of six patients with ocular lymphoma

\begin{tabular}{|c|c|c|c|c|c|c|c|c|c|c|c|}
\hline & Symptoms & Var Val & $\begin{array}{l}\text { Colour } \\
\text { ishihara }\end{array}$ & Fine $K P$ & $I O P$ & Vit cells & RET infil & $\begin{array}{c}R P E \\
\text { change }\end{array}$ & $\begin{array}{l}\text { VASC } \\
\text { change }\end{array}$ & $\begin{array}{c}\text { Optic } \\
\text { disc }\end{array}$ & Other \\
\hline $177 \mathrm{M}$ & $\begin{array}{l}\text { Black spots in } \\
\text { morning. } \\
\text { Progressive } \\
\text { deterioration } \\
\text { of vision }\end{array}$ & $6 / 126 / 36$ & Absent & $J$ & Normal & $\begin{array}{l}\text { Cells }++ \\
\text { Opacities } \\
++\end{array}$ & $J$ & $\sqrt{ }$ & Attenuated & Normal & 一 \\
\hline $264 \mathrm{M}$ & $\begin{array}{l}\text { "Jelly curtain" } \\
\text { Cloudy vision. } \\
\text { In morning. } \\
\text { Tunnel vision. }\end{array}$ & $6 / 186 / 18$ & Reduced & 一 & Normal & $\begin{array}{l}\text { Cells }++ \\
\text { Opacities } \\
++\end{array}$ & $\sqrt{ }$ & - & - & Normal & - \\
\hline $372 \mathrm{~F}$ & $\begin{array}{c}\text { Black net } \\
\text { floater. } \\
\text { Progressive } \\
\text { deterioration. }\end{array}$ & 6/36 NPL & Reduced & $\downarrow$ & Raised & $\begin{array}{l}\text { Cells }++ \\
\text { Opacities } \\
++\end{array}$ & $\begin{array}{c}ل \\
\text { Especially } \\
\text { in macular } \\
\text { area }\end{array}$ & & $\begin{array}{l}\text { Narrow } \\
\text { vessels }\end{array}$ & Atrophic & - \\
\hline $480 \mathrm{~F}$ & $\begin{array}{c}\text { Progressive } \\
\text { deterioration } \\
\text { of vision }\end{array}$ & NPL 6/60 & Absent & - & Raised & Cells + & J & - & $\begin{array}{l}\text { Haemorrhage } \\
\text { Narrow } \\
\text { vessels }\end{array}$ & Atrophic & - \\
\hline $573 \mathrm{~F}$ & Floaters & $6 / 186 / 36$ & Absent & $\sqrt{ }$ & Raised & Cells + + & $\sqrt{ }$ & - & - & 一 & \\
\hline $664 \mathrm{M}$ & $\begin{array}{l}\text { Blurred vision } \\
\text { in both eyes }\end{array}$ & $6 / 56 / 5$ & Full & - & Raised & Cells + + & 一 & 一 & 一 & - & $\begin{array}{l}\text { No focal } \\
\text { retinal } \\
\text { features }\end{array}$ \\
\hline
\end{tabular}

infiltrates (Fig 1) and pigment epithelial abnormalities. Four patients (Nos 1-4) had large areas of retina which appeared pale due to the presence of subretinal infiltrates particularly around the posterior pole. In patients 1 and 3 these infiltrates appeared like mushrooms on the surface of the retina. Additional pigment epithelial disease was seen in patient 1 . Both blind eyes (patients 3 and 4) had optic atrophy and marked vascular constriction in addition to the sub-retinal infiltrates and patient 6 did not show any focal abnormalities.

(iv) Fluorescein angiography (Table III) Four patients had fluorescein angiography: patient 1 had angiography following vitrectomy but before treatment: diffuse pigment epithelial disturbance was observed with some late disc leakage but no retinal vascular abnormality or macular oedema despite the appearance of the macula on fundoscopy. (Fig 2) Patient 2 showed window defects in the epithelium and some staining of the retinal veins in the late pictures. Patient 3 had angiography after treatment with radiotherapy and recurrence of her symptoms of blurred vision. Unfortunately the pictures were very hazy but no obvious focal abnormality was present. Patient 4 revealed pigment epithelial changes, with constricted retinal vessels, minimal macular oedema and late disc leakage.

(v) Electrodiagnostic Studies (patient 1 only)

The electrooculogram light rise was totally abolished in each eye and the rod mediated electroretinogram (ERG) subnormal. The cone mediated ERG was also sub-normal with poor response to early flicker ERG fusion. The pattern visual evoked response (VER) was completely abolished for the left eye and vir-

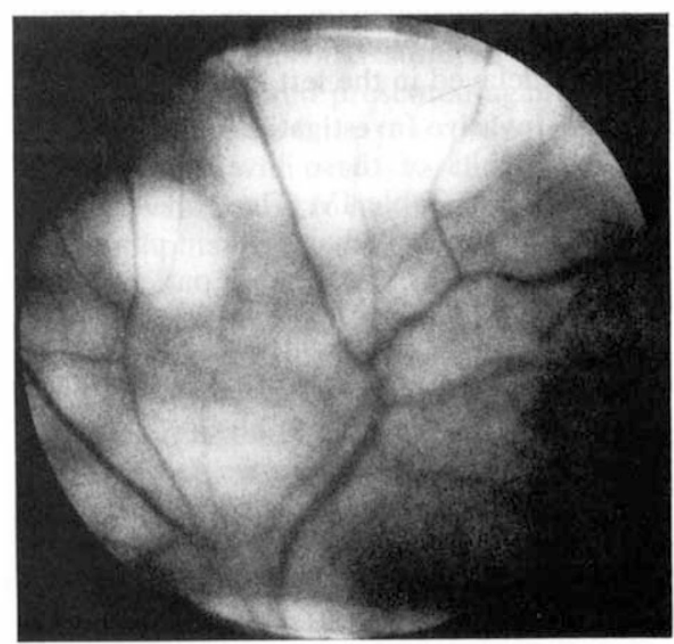

Fig. 1. Patient 2. Fundus photograph of the left eye showing large sub-retinal infiltrates. 
Table III Fluorescein features of four patients with ocular lymphoma

\begin{tabular}{lcccc}
\hline Patient & $\begin{array}{c}\text { Retinal pigment } \\
\text { epithelial abnormality }\end{array}$ & $\begin{array}{c}\text { Retinal vascular } \\
\text { abnormality }\end{array}$ & $\begin{array}{c}\text { Macular } \\
\text { oedema }\end{array}$ & $\begin{array}{c}\text { Disc } \\
\text { leakage }\end{array}$ \\
\hline 1 & Diffuse & Nil & Nil & Late \\
2 & Diffuse & Staining in late & Nil & Nil \\
$3($ After DXT) & Nil & Nil & Nil & Late \\
4 & Diffuse & Constricted retinal & vessels & Minimal \\
& & & Late \\
\hline
\end{tabular}

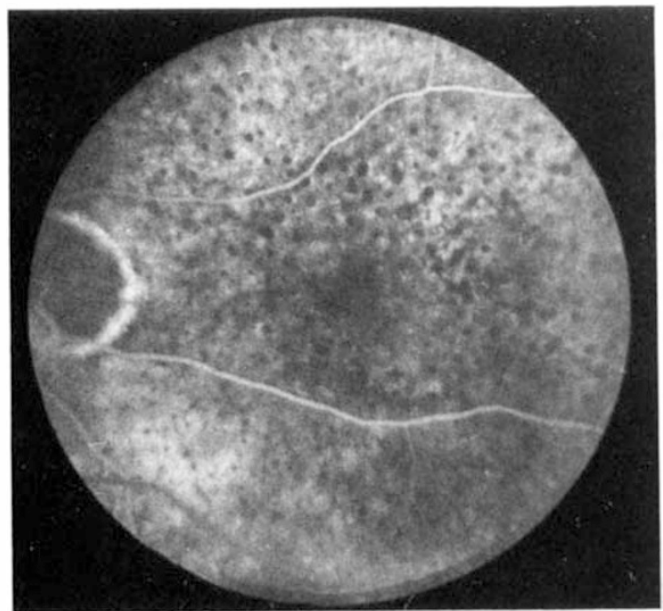

Fig. 2. Patient 1. Late phase fluorescein angiogram of left eye (post diagnostic vitrectomy) showing diffuse pigment epithelial defects and attenuated retinal vessels.

tually abolished in the right eye. The flash VER was sub-normal in both eyes but only delayed in the left eye.

B. Non-Invasive Investigations

The results of these investigations are detailed in Table IV. The bone marrow examination was diagnostic in patients 1 and 5 and was abnormal in patient 3 but she had previously had a gastrectomy and these findings were probably secondary to this rather than a direct result of the lymphoma. CSF examination revealed the same atypical lymphocytes in the bone marrow in patient 1 together with a raised protein. Patient 2 also showed an increased protein level in his CSF. Oligoclonal bands were not seen in any patient. Patient 1 and 5 had abnormal immunoglobulins reflecting the diseased lymphopoietic system. CT scan of the brain was a disappointing investigation and was abnormal at this stage in only 2 patients: patient 4 who had an unrelated calcified vertex meningioma and patient 6 who showed multiple deposits of his lymphoma. He had been diagnosed 8 months previously and presented with cranial nerve palsies at the same time as blurred vision. Hence in two patients these investigations confirmed the clinical diagnosis and in three added supportive evidence of lymphoma. In only one patient (patient 5) were the investigations entirely unhelpful.

C. Response to Therapy (Fig. 3)

Four patients (Nos. 1-4) received treat ment for their ocular condition. Patients 2, 3 and 4 received systemic steroids (Prednisolone $80 \mathrm{mg}$ daily reducing over 6 weeks): two noticed a slight improvement in one eye but no change in the other and the third patient's vision deteriorated from $6 / 60$ to no perception of light during the course of treatment. These four patients received a course of radiotherapy: (25 Gy): rapid visual improvement occurred in four eyes, no change in three and one deteriorated. In all the eyes which did not respond to radiotherapy there was marked constriction of retinal vessels prior to treatment.

\section{Discussion}

The clinical features of our six patients correlate well with the many cases previously described ${ }^{6}$ Elderly patients present with large cells in the vitreous of both eyes associated with sub-retinal infiltrates and pigment epithelial lesions progressing to attenuated retinal vessels and optic atrophy. Variable 
Table IV Non-invasive investigations in six patients at presentation with ocular lymphoma

\begin{tabular}{|c|c|c|c|c|c|c|}
\hline Patient & Full blood count & Bone marrow & Plasma proteins & $C S F$ & $C T$ scan & Others \\
\hline 1 & $\sqrt{ }$ & $\begin{array}{c}\text { Hypocellular } \\
\text { Atypical lymphocytes }\end{array}$ & Raised IgA & $\begin{array}{c}\text { Protein } 0.7 \mathrm{~g} / \mathrm{l} \\
6 \text { atypical lymphs }\end{array}$ & $\sqrt{ }$ & $\begin{array}{c}\text { Bone scan } \\
\text { showed } \\
\text { sclerotic lesion } \\
\text { in vertebra }+ \text { hip }\end{array}$ \\
\hline 2 & - & $\sqrt{ }$ & $J$ & Protein $0.7 \mathrm{~g} / \mathrm{l}$ & J & SACE normal \\
\hline $3^{*}$ & $\begin{array}{l}\text { Thrombocytosis } \\
\text { Megaloblastic } \\
\text { film }\end{array}$ & $\begin{array}{c}\text { Hypocellular } \\
\text { Megakaryocytes }\end{array}$ & j & J & $\sqrt{ }$ & SACE normal \\
\hline 4 & $\begin{array}{l}\text { Normal film } \\
\text { ESR } 22\end{array}$ & 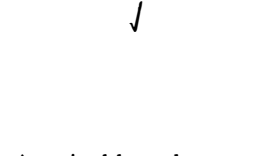 & J & - & $\begin{array}{l}\text { Calcified } \\
\text { vertex } \\
\text { meningioma } \\
\text { No signs } \\
\text { lymphoma }\end{array}$ & J \\
\hline 5 & Normal film & Atypical lymphocytes & $\begin{array}{l}\text { Raised IgM } \\
\text { Paraprotein } \\
\text { Reduced IgA } \\
\text { and IgG }\end{array}$ & - & J & - \\
\hline 6 & ESR 22 & - & IgM paraprotein & $\begin{array}{c}\text { Protein } 1.3 \mathrm{~g} / 1 \\
17 \text { atypical } \\
\text { lymphocytes }\end{array}$ & $\begin{array}{l}\text { Multiple } \\
\text { lesions }\end{array}$ & 一 \\
\hline
\end{tabular}

${ }^{*}$ Patients known to have lymphoma prior to presentation with ocular symptoms.

$\checkmark$ Results within normal limits.

-Investigation not performed.

\section{Effect of Treatment on Visual Acuity}

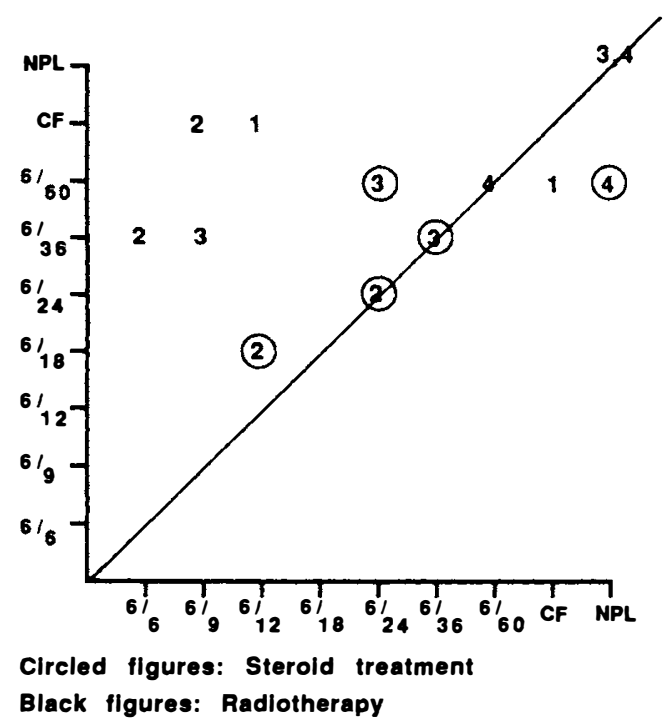

Fig. 3. Effects of treatment with steroids and radiotherapy on the visual acuities of four patients.

features include fine keratic precipitates, raised intraocular pressure, serous retinal detachment. The condition is refractory to treatment with steroids but responsive to radiotherapy. ${ }^{5}$ Ocular lymphoma is an important cause of posterior uveitis or painful blind eyes particularly in elderly people. Uveitis affects young people more commonly than elderly people: Figure 4 shows the causes of endogenous, non-infective uveitis in 368 people attending the Medical Eye Unit between 1976 and 1982.334 of these patients were under 55 years of age: the majority of the 34 elderly patients had suffered an earlier attack of uveitis and presented again with a recurrence in their later years. Most patients who presented with uveitis for the first time at this age were found to have ocular ischaemia or lymphoma, and only one patient had sarcoidosis.

The clinical features of ocular ischaemia are mild anterior uveitis, abnormal intraocular pressure (high or low), rubeosis, few cells in the vitreous, attenuated retinal arterioles, dilated veins with microaneurysms and haemorrhages, macular oedema and low central retinal artery pressure. ${ }^{7}$ Signs of carotid artery disease may also be present with reduced pulses and a carotid bruit. This condition is similar to ocular lymphoma by being refractory to steroids. 


\section{Causes of Endogenous Uveitis In 368 Patients}

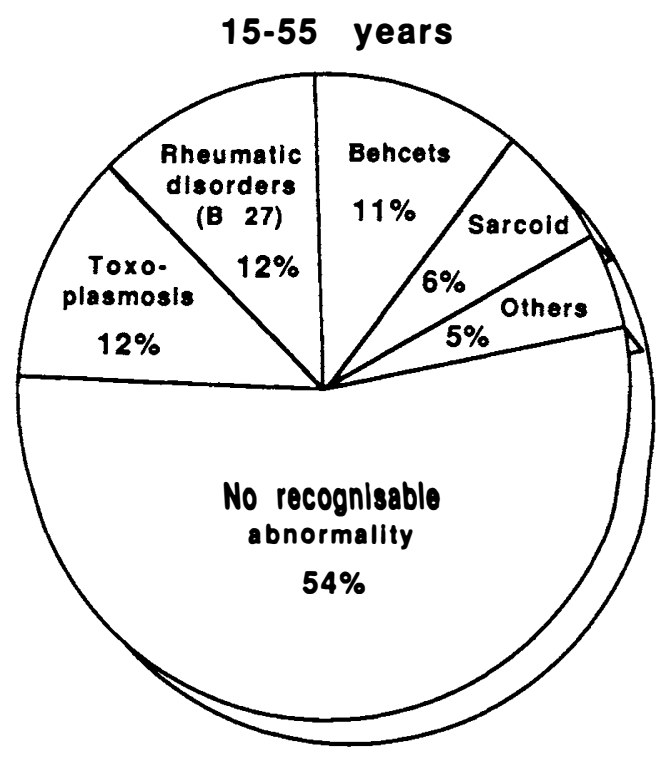

Over 55 years

Fig. 4. The causes of endogenous uveitis in 368 patients attending the Medical Eye Unit between 1976 and 1982.

Sarcoidosis and Behçet's disease are rare in patients over 50 years and usually present in the 2nd and 3rd decades. Sarcoidosis is classically associated with iris nodules, periphlebitis, disc oedema and pigment epithelial defects. ${ }^{8}$ Behçet's disease may present with severe pan uveitis and frequently produces branch retinal vein occlusions, capillary leakage, and disc oedema. Retinal infiltrates occur which are in the superficial, retinal layers and resolve rapidly with steroids. ${ }^{9}$

Patients with ocular lymphoma develop severe loss of visual function with relatively mild posterior uveitis early in their disease. Review of the clinical features of our patients showed constricted visual fields and reduced colour vision in addition to reduction in visual acuity. Fluorescein angiograms were performed on four of our patients and revealed extensive pigment epithelial disease and constricted retinal vessels; however marked leakage from the vessels, the optic disc, or macular oedema was not observed. Three reports of fluorescein angiography in ocular lymphoma describe diffuse pigment epithelial abnormality in two patients ${ }^{10.11}$ and no abnormality in one other. ${ }^{12}$ These findings differentiate patients with ocular lymphoma from patients with uveitis due to other causes such as sarcoidosis where colour vision and visual fields are usually preserved and macular oedema is the main reason for loss of central vision. ${ }^{13}$

The clinical features of reduced colour vision and constricted visual fields suggest early involvement of the optic nerve and retina as the cause of visual loss. These observations are supported by histopathological evidence: tumour cells are condensed between the pigment epithelium and Bruch's membrane and infiltrating the optic nerve head to the level of the lamina cribrosa. ${ }^{1.14 .15,16,17}$ Perivascular cuffing is frequently seen in the retinal blood vessels ${ }^{6}$ but tumour cells rarely infiltrate the vessel walls. Involvement of the choroid with tumour cells is unusual ${ }^{18}$ but the iris, ciliary body and vitreous are often heavily infiltrated. ${ }^{1,6.16}$ Examination of cases with advanced disease show degeneration of the photoreceptor layer and the retinal pigment epithelium ${ }^{11}$ with gliosis of the optic nerve. ${ }^{1,15}$ The tumour cells are characteristically large pleomorphic cells with 
Table V Characteristic clinical features of ocular lymphoma

\begin{tabular}{lccc}
\hline History & Examination & Fluorescein angiography & Treatment \\
\hline$>55$ years & Constricted visual field & Pigment epithelial disease & Poor response to steroids \\
Bilateral disease & Reduced colour vision & Good response to \\
Fluctuating vision & Vitreous cells & & radiotherapy \\
& subretinal infiltrates & &
\end{tabular}

scanty cytoplasm, a large irregular nucleus and prominent eosinophilic nucleoli. ${ }^{19}$ The pathological spectrum may vary: three patients have been described with proven cerebral lymphoma and uveitis but pathological examination has revealed lymphomatous cells in the vitreous but not in the retina or uvea. ${ }^{1,14.20}$ Two younger patients, aged 49 and 33 years respectively presented with posterior uveitis nine months before development of neurological disease due to cerebral lymphoma. Both patients were found at autopsy to have inflammatory cells in the vitreous but no evidence of intraocular lymphoma ${ }^{21.22}$ and it was hence postulated that the inflammatory reaction might precede the infiltration of the eye by neoplastic cells. The ocular inflammation' is relatively insensitive to steroids and sensitive to radiotherapy, ${ }^{5,23}$ although in the initial phases of the disease steroids may produce some benefit. ${ }^{24.25}$ These observations presumably reflect the presence of inflammatory cells together with tumour cells in the initial phase of the disease. ${ }^{1}$ As the disease progresses tumour cells out-number inflammatory cells and consequently only radiotherapy will be effective although treatment must be given before photoreceptor degeneration, vascular constriction and optic atrophy ensue.

Radiotherapy is often delayed because of difficulty in confirming the clinical diagnosis: vitrectomy may be the investigation of choice but often yields only chronic inflammatory cells and no evidence of lymphoma. Retinal biopsy should have a higher diagnostic yield but requires hypotensive anaesthesia, which may not be advisable in elderly patients. In order to circumvent this delay, we reviewed our patients and those in the literature to isolate the significant diagnostic findings. This resulted in eliciting the following clinical features as most characteristic of ocular lymphoma (Table V):
(1) Age (more than 55 years) at presentation.

(2) Bilateral disease.

(3) Constricted visual field with reduced or absent colour vision.

(4) Fine pigmented keratic precipitates, large profuse vitreous cells and subretinal infiltrates.

(5) Pigment epithelial abnormality without associated macular oedema or fluorescein angiography.

(6) Poor response to treatment with systemic steroids.

In patients with some or all of these features, and particularly when associated with neurological signs, the standard 'uveitis survey' should be expanded to include:

(1) Bone marrow examination.

(2) Plasma protein and immunoglobulins estimation.

(3) Cerebrospinal fluid examination.

(4) CT scan of the brain.

In the majority of patients these investigations will yield presumptive evidence of lymphoma and in these circumstances radiotherapy can be contemplated without the necessity of final histological confirmation. In the occasional patient in whom all these investigations are normal, the clinician is left with the alternative of vitreous or retinal biopsy or a therapeutic trail of radiotherapy. Clinical experience may dictate the latter rather than infliction of multiple surgical procedures.

I thank Mr Sanders for his advice and Mr Hart, Professor McDonald, Miss James, Mr Quinlan and Dr Kocen for allowing me to report on patients under their care; Miss Deborah Clutterbuck for secretarial assistance and Mr Richard Dewhirst for preparation of the illustrations.

\section{References}

${ }^{1}$ Vogel MH, Font R, Zimmerman LE, Levine RA: Reticulum cell sarcoma of the retina and uvea. Am J Ophthalmol 1968, 66: 205-15. 
${ }^{2}$ Cooper EL and Riker JL. Malignant lymphoma of the uveal tract. Am J Ophthalmol 1961, 34: 1153

${ }^{3}$ Neault RW, Van Scoy RE, Okazaki H and MacCarty $\mathrm{CS}$. Uveitis associated with isolated reticulum cell sarcoma of the brain. Am J Ophthalmol 1972, 73: 431-6.

${ }^{4}$ Kaplan HJ, Meredith TA, Aaberg JM, Keller RH: Reclassification of intraocular reticulum cell sarcoma (Histiocytic lymphoma). Arch Ophthalmol 1980, 98: 707-10.

${ }^{5}$ Margolis L, Fraser R, Lichter A, Char DH: The role of radiation therapy in the management of ocular reticulum cell sarcoma. Cancer 1980, 45: 688-92.

${ }^{6}$ Green WR: Ocular Reticulum cell sarcoma. In: Fine, SL and Owens SL. Eds. Management of retinal vascular and macular disorders. Baltimore: Williams and Wilkins. 1983; 249-264.

${ }^{7}$ Sarkies NJC, Shilling JS, Ross Russell RW: Fluorescein angiography in carotid disease. Trans Ophthalmol Soc UK 1986, 105: 489-93.

${ }^{8}$ Graham EM: Ocular involvement in sarcoidosis. Seminars in Respiratory Medicine. 1986, 8: 59-64.

${ }^{9}$ Michelson JB and Chisari FV: Behçet's disease. Surv Ophthalmol 1982, 26: 190-203.

${ }^{10}$ Simon JW and Friedmann AH: Ocular reticulum cell sarcoma. Br J Ophthalmol 1980, 64: 793-9.

${ }^{11}$ Lang GK, Surer JL, Green WR, Finkelstein D, Michels RG, Maumenee E: Ocular reticulum cell sarcoma. Clinicopathological correlation of a case with multifocal lesions. Retina 1985, 5: 79-86.

12 Michels RG, Knox DL, Erozan YS, Green WR: Intraocular reticulum cell sarcoma. Arch Ophthalmol 1975, 93: 1331-5.

${ }^{13}$ Dumonde DC, Kasp Grochowska E, Graham E, Sanders MD, Faure JP, De Kozak Y, Van Tuyen $\mathrm{V}$ : Antiretinal autoimmunity and circulating immune complexes in patients with retinal vasculitis. Lancet 1982: ii 787-92.

${ }^{14}$ Nevins RC, Frey WW, Elliott JH: Primary, solitary, intraocular reticulum cell sarcoma (micro- gliomatosis). A clinicopathological case report. Trans Amer Acad Ophthalmol and Otol 1968, 72: 867-76.

${ }^{15}$ Harstad HK and Arnesen K: Malignant lymphoma of the eye and the brain. Acta Ophthalmol 1974, 52: 211-9.

${ }^{16}$ Barr CC, Green WR, Payne JW, Knox DL, Jenson AD, Thompson RL: Intraocular reticulum cell sarcoma: clinicopathological study of four cases and review of the literature. Survey Ophthalmol 1975, 19: 224-39.

${ }^{17}$ Kim EW, Zakov N, Albert DM, Smith TR, Craft JL: Intraocular reticulum cell sarcoma: A case report and literature review. AlvGr Arch Ophthalmol, 1979, 209: 167-78.

${ }^{18}$ Klingele TG and Hogan MJ: Ocular reticulum cell sarcoma. Am J Ophthalmol 1975, 79: 39-47.

${ }^{19}$ Michelson JB, Michelson PE, Bordin GM, Chisari FV: Ocular reticulum cell sarcoma. Arch Ophthalmol 1981, 99: 1409-11.

${ }^{20}$ Minckler DS, Font RL, Zimmerman LE: Uveitis and reticulum cell sarcoma of brain with bilateral neoplastic seeding of vitreous without retinal or uveal involvement. Am J Ophthalmol 1975, 80: 433-9.

${ }^{21}$ Givner I: Malignant lymphoma with ocular involvement. Am J Ophthalmol 1955, 39: 29-32.

22 Kennerdell JS, Johnson BL, Wisotzkey HM: Vitreous cellular reaction. Association with reticulum cell sarcoma of brain. Arch Ophthalmol 1975, 93: 1341-5.

${ }^{23}$ Char DH, Margolis L, Newman AB: Ocular reticulum cell sarcoma. Am J Ophthalmol 1981, 91: 480-3.

${ }^{24}$ Scully RE, Mark EJ, McNeely BU (Eds): Case records of the Massachusetts General Hospital. Weekly clinicopathological exercises. Case 33-1985. N Eng J Med 1985, 313: 436-43.

${ }^{25}$ Sloas HA, Starling J, Harper DG, Cupples HP: Update of ocular reticulum cell sarcoma. Arch Ophthalmol 1981, 99: 1048-52. 